\section{Oral and maxillofacial surgery - a case of mistaken identity?}

D. R. van Gijn ${ }^{1}$

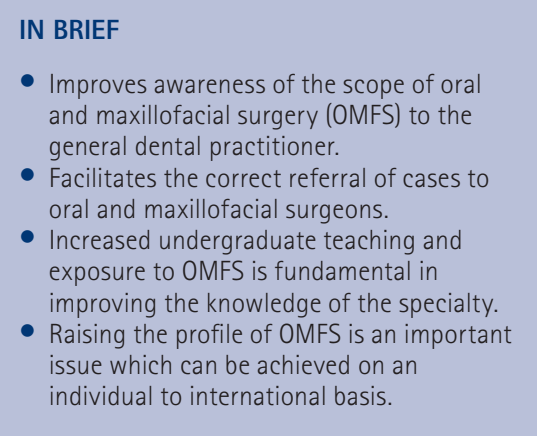

There are international grumbles from those perturbed by an impending identity crisis within oral and maxillofacial surgery (OMFS). This unrest is further compounded by scattered suggestions that a name change may prove beneficial in raising the profile of OMFS. The purpose of this paper is to consider novel methods of increasing awareness of the specialty amongst the public, primary and secondary care colleagues by collecting a consensus of thoughts and opinions regarding the specialty's identity and the appropriate and holistic nomenclature of OMFS. Approximately 300 eight-point questionnaires were distributed internationally with a response rate, via both email and post, of approximately $25 \%$ (72). Thirty-two percent of respondents considered there to be an identity crisis within OMFS although just 18\% felt that a specialty name change would be beneficial. The results suggest that the problem with identity relates more to incapacity to convey the message of OMFS rather than nomenclature.

\section{INTRODUCTION}

Oral and maxillofacial surgery (OMFS) is a unique specialty - not only in its requirements for both dental and medical training, but also in its wide spectrum of pathology, close affiliation with oral surgery and significant overlap with specialties such as ear, nose and throat and plastic surgery. The aforementioned factors complicate outstanding uncertainties amongst both the general public and dental colleagues regarding the specialty's surgical scope and the subsequent and appropriate provision of care.

The unrest that abounds within OMFS - concerned with its perceived fragile identity amongst better known specialties - is further compounded by suggestions that a change of specialty name may be beneficial in raising its profile. The purpose of this paper is to determine the prevailing views on the aforementioned

${ }^{1}$ Specialist Trainee Maxillofacial Surgery, 10 Bruce Road, Mitcham, Surrey, CR4 2BG

Correspondence to: Dr Daniel R. van Gijn

Email: danielvangijn@doctors.org.uk

\section{Refereed Paper}

Accepted 6 August 2010

DOI: 10.1038/sj.bdj.2010.1180

${ }^{\circledR}$ British Dental Journal 2011; 210: 9-11 themes and to consider novel methods of increasing awareness of the specialty amongst the public, primary and secondary care colleagues.

\section{METHOD}

An eight-point questionnaire was distributed by electronic mail to addresses of consultants and specialist registrars (or equivalent) listed on the web pages of the British and International Associations of Oral and Maxillofacial Surgery. Questions distributed were as follows:

- Do you feel your hospital colleagues are fully aware of the scope and provision of the specialty?

- Do you feel that general medical practitioners are fully aware of the scope and provision of the specialty?

- Are inappropriate referrals from colleagues/general practitioners a problem?

- Do you feel that maxillofacial surgery suffers from an identity crisis?

- Do you feel that a contributing factor in the uncertainty regarding the scope and provision of the specialty lies in the name of the specialty (ie oral and maxillofacial surgery)?

- Do you feel a name change would be beneficial in raising the profile of the specialty?

\section{RESULTS}

Approximately 300 questionnaires were distributed internationally with a response rate, via both email and post, of approximately 25\% (72).

The questionnaire was returned by OMFS departments from the USA and Canada, United Kingdom and the Isle of Wight, Austria, Italy, Germany, Spain, South Africa, Australia and New Zealand - providing wide international representation. Thirty-two percent of respondents considered there to be an identity crisis within OMFS although just 18\% felt that a specialty name change would be beneficial. A full breakdown of questionnaire results can be found in Table 1. Suggestions for a specialty name change, provided by the returned questionnaires, included facial and oral surgery, orofacial surgery, head and neck surgery and face, mouth and jaw surgery. Further suggestions for raising the profile of oral and maxillofacial surgery can be found in Table 2 .

\section{DISCUSSION}

The results suggest that the problems with identity within OMFS relate more to an incapacity to convey the message rather than nomenclature. An interesting observation from the study is that the majority of respondents did not feel that a name change 


\begin{tabular}{|c|c|c|c|c|c|c|}
\hline $\begin{array}{l}\text { Country of origin } \\
\text { of respondent }\end{array}$ & $\begin{array}{l}\text { Number of } \\
\text { respondents }\end{array}$ & $\begin{array}{l}\text { Are hospital } \\
\text { colleagues aware } \\
\text { of scope? }\end{array}$ & $\begin{array}{l}\text { Are general } \\
\text { practitioners } \\
\text { aware of scope? }\end{array}$ & $\begin{array}{l}\text { Are inappropri- } \\
\text { ate referrals a } \\
\text { problem? }\end{array}$ & $\begin{array}{l}\text { Is there an identity } \\
\text { crisis within } \\
\text { OMFS? }\end{array}$ & $\begin{array}{l}\text { Would a name } \\
\text { change be helpful? }\end{array}$ \\
\hline USA & 11 & $\begin{array}{l}\text { Yes: } 5 \\
\text { No: } 6\end{array}$ & $\begin{array}{l}\text { Yes: } 5 \\
\text { No: } 5 \\
\text { Unsure: } 1\end{array}$ & $\begin{array}{l}\text { Yes: } 2 \\
\text { No: } 7 \\
\text { Unsure: } 2\end{array}$ & $\begin{array}{l}\text { Yes: } 7 \\
\text { No: } 2 \\
\text { Unsure: } 2\end{array}$ & $\begin{array}{l}\text { Yes: } 2 \\
\text { No: } 6 \\
\text { Unsure: } 3\end{array}$ \\
\hline UK & 46 & $\begin{array}{l}\text { Yes: } 27 \\
\text { No: } 14 \\
\text { Unsure: } 5\end{array}$ & $\begin{array}{l}\text { Yes: } 17 \\
\text { No: } 21 \\
\text { Unsure: } 8\end{array}$ & $\begin{array}{l}\text { Yes: } 22 \\
\text { No: } 16 \\
\text { Unsure: } 8\end{array}$ & $\begin{array}{l}\text { Yes: } 12 \\
\text { No: } 25 \\
\text { Unsure: } 9\end{array}$ & $\begin{array}{l}\text { Yes: } 7 \\
\text { No: } 25 \\
\text { Unsure: } 14\end{array}$ \\
\hline Germany & 4 & $\begin{array}{l}\text { Yes: } 2 \\
\text { No: } 2\end{array}$ & $\begin{array}{l}\text { Yes: } 1 \\
\text { No: } 3\end{array}$ & $\begin{array}{l}\text { Yes: } 1 \\
\text { No: } 3\end{array}$ & No: 4 & No: 4 \\
\hline Spain & 1 & Yes: 1 & Unsure: 1 & Yes: 1 & No: 1 & Yes: 1 \\
\hline Canada & 2 & Yes: 2 & $\begin{array}{l}\text { Yes: } 1 \\
\text { No: } 1\end{array}$ & No: 2 & $\begin{array}{l}\text { Yes: } 1 \\
\text { Unsure: } 1\end{array}$ & No: 2 \\
\hline South Africa & 1 & No: 1 & No: 1 & Yes: 1 & Unsure: 1 & Yes: 1 \\
\hline Austria & 1 & No: 1 & No: 1 & Yes: 1 & Yes: 1 & Yes: 1 \\
\hline Italy & 1 & Yes: 1 & Yes: 1 & Yes: 1 & No: 1 & No: 1 \\
\hline Australia & 3 & Yes: 3 & $\begin{array}{l}\text { Yes: } 2 \\
\text { No: } 1\end{array}$ & $\begin{array}{l}\text { Yes: } 1 \\
\text { No: } 2\end{array}$ & $\begin{array}{l}\text { Yes: } 2 \\
\text { No: } 1\end{array}$ & $\begin{array}{l}\text { Yes: } 1 \\
\text { No: } 2\end{array}$ \\
\hline New Zealand & 1 & Yes: 1 & Unsure: 1 & No: 1 & No: 1 & No: 1 \\
\hline Isle of Wight & 1 & No: 1 & No: 1 & Yes: 1 & Unsure: 1 & No: 1 \\
\hline Totals & 72 & $\begin{array}{l}\text { Yes: } 42(58 \%) \\
\text { No: } 25(35 \%) \\
\text { Unsure: } 5(7 \%)\end{array}$ & $\begin{array}{l}\text { Yes: } 27(38 \%) \\
\text { No: } 34(47 \%) \\
\text { Unsure: } 10(14 \%)\end{array}$ & $\begin{array}{l}\text { Yes: } 31(43 \%) \\
\text { No: } 31(43 \%) \\
\text { Unsure: } 10(14 \%)\end{array}$ & $\begin{array}{l}\text { Yes: } 23(32 \%) \\
\text { No: } 35(49 \%) \\
\text { Unsure: } 14(19 \%)\end{array}$ & $\begin{array}{l}\text { Yes: } 13(18 \%) \\
\text { No: } 42(58 \%) \\
\text { Unsure: } 17(24 \%)\end{array}$ \\
\hline
\end{tabular}

would be beneficial in addressing a crisis of identity, with the overriding consensus being that the current denomination is representative of the scope of the specialty - it is unique, reflects its dental basis and its maxillofacial objective as a broader theatre of operation. Furthermore, respondents felt it underpins the wider scope of its clinical, anatomical and pathological involvement. In adherence with the vast majority of responses obtained, it is the author's opinion that a name change may further confuse an already confused situation. A nominal suggestion is the addition of a layman title akin to 'otolaryngology' and 'ear, nose and throat' - lay persons' nomenclature versus professional speak. In common usage is the abbreviation 'maxfac' or 'maxfax', which is distinctly more sustainable, memorable and referable than 'oral and maxillofacial surgery.' Attempts directed at publicising the former may prove beneficial in improving public knowledge of the specialty and indirectly, its scope and capabilities.

A significant proportion of respondents raised the importance of utilising media as a means for raising the specialty's profile. We live in a technologically advanced, consumer-driven generation in which

\section{Table 2 Selected list of additional suggestions raised by questionnaire responders}

Additional suggestions

Continuous education and liaison with our colleagues in primary and secondary care (presentations, courses, board meetings etc)

Embrace (and clarify) dual qualification - doubling of our target audience and media potential

A final and universal consensus with regard to dual qualification - a significant proportion of potential trainees interested are dissuaded from a career in OMFS because of relative uncertainty. These and other uncertainties do little to attract potential trainees

Clinical audit ('proof') to provide informed opinion on best placed provision of care

Continue to train OMFS in contemporary specialty, appoint well trained and skilled individuals into hospital and academic posts and provide comprehensive service

Better integration of OMFS into curriculum of medical students

Send out comprehensive lists of our scope to GMPs and GDPs

Continue to publish in international journals and present at combined international conferences and raise our profile by what we do in our own hospitals

businesses rely on media - including print, electronic and advertisements - in order to gain widespread public attention, recognition and sustenance. A key component in improving the public profile of any business involves the synergistic collaboration of relevant, successful and widely advertised companies. The spectrum of such affiliations extends from highly publicised world events, such as the wars in Iraq and Afghanistan, to multibillion pound global industries. The key to marketing the specialty of oral and maxillofacial surgery - and in turn successfully enhancing its public image - lies in our ability to recognise some of the aforementioned resources and attach some of the components of our specialty's scope to (largely) relevant and contemporary media examples. Related suggestions from returned questionnaires included the enrollment of a public relations officer as part of the 
British and International Association of Oral and Maxillofacial Surgeons.

Furthermore, respondents to the questionnaire also raised the importance of increasing undergraduate (both medical and dental) exposure to oral and maxillofacial surgery as a means of indirectly enhancing its profile. There is certainly exposure to the speciality during dental undergraduate training, and in some instances beyond graduation. This exposure, coupled with a close and everyday affiliation with oral surgeons, can only serve to improve those individuals' knowledge of the specialty's surgical scope and in turn, their ability to refer appropriately and provide holistic patient care. However, unfortunately the same cannot be said of undergraduate medical training, where the oral cavity in its entirety (let alone its surrounding bony architecture) is a topic seldom discussed - particularly within the breath of a surgical sentence. To further compound the paucity of medical undergraduate exposure to oral and maxillofacial surgery, foundation posts in OMFS are few and far between.

This questionnaire has presented two important points. Firstly, there is a majority opinion that general practitioners (principally medical) are not fully aware of the scope of OMFS. The second consensus amongst respondents is that a change in the nomenclature of OMFS will not be of benefit in improving any existing confusion regarding the specialty's surgical scope. Efforts must therefore be re-directed towards addressing agreed-upon issues in particular that of increasing the exposure of OMFS to medical undergraduates and foundation year doctors - rather than the unnecessary physical, economic and temporal expenditure involved with issues such as a change of name. 